REVIEW

EJE PRIZE 2013

\title{
Regulation of aldosterone secretion: from physiology to disease
}

Felix Beuschlein

Endocrine Research Unit, Medizinische Klinik und Poliklinik IV, Klinikum der Universität München, Ziemssenstrasse 1, D-80336 Munich, Germany

(Correspondence should be addressed to F Beuschlein; Email: felix.beuschlein@med.uni-muenchen.de)

This article is based on the presentation for the European Journal of Endocrinology Prize Lecture 2013 at the European Society of Endocrinology Meeting at Copenhagen, Denmark

\begin{abstract}
Arterial hypertension is a major cardiovascular risk factor that affects between 10 and $40 \%$ of the population in industrialized countries. Primary aldosteronism (PA) is the most common form of secondary hypertension with an estimated prevalence of around $10 \%$ in referral centers and $4 \%$ in a primary care setting. Despite its high prevalence until recently, the underlying genetic and molecular basis of this common disease had remained largely obscure. Over the past decade, a number of insights have been achieved that have relied on in vitro cellular systems, wild-type and genetically modified in vivo models, as well as clinical studies in well-characterized patient populations. This progress has been made possible by a number of independent technical developments including that of specific hormone assays that allow measurement in small sample volumes as well as genetic techniques that enable high-throughput sequencing of a large number of samples. Furthermore, animal models have provided important insights into the physiology of aldosterone regulation that have served as a starting point for investigation of mechanisms involved in autonomous aldosterone secretion. Finally, national and international networks that have built up registries and biobanks have been instrumental in fostering translational research endeavors in PA. Therefore, it is to be expected that in the near future, further pathophysiological mechanisms that result in autonomous aldosterone secretion will be unraveled.
\end{abstract}

European Journal of Endocrinology 168 R85-R93

\section{Clinical background}

Hypertension is a major cardiovascular risk factor that affects between 10 and $40 \%$ of the general population in an age- and population-dependent manner $(1,2)$. The renin-angiotensin-aldosterone system (RAAS) is regulating blood pressure, fluid volume, and the vascular response to injury and inflammation (3). Chronic RAAS activation leads to persistent hypertension, setting off a cascade of inflammatory, thrombotic, and atherogenic effects eventually leading to end-organ damage $(4,5)$. Accordingly, numerous studies have demonstrated that elevated aldosterone levels are predictors of adverse outcome in hypertension (6), heart failure $(7,8)$, myocardial infarction (9), and renal insufficiency (10). Primary aldosteronism (PA) is the most common secondary form of hypertension with an estimated prevalence of around $4 \%$ in hypertensive patients in primary care and around $10 \%$ in those referred to specialized centers (11). Accordingly, a high proportion (between 11 and 20\%) of PA is present in patients that are resistant to combined antihypertensive medical treatment $(12,13)$. PA is currently the most common curable form of hypertension (14). Given the detrimental cardiovascular adverse effects of aldosterone excess that are independent of high blood pressure levels $(15,16,17,18)$, early detection of PA has an important impact on clinical outcome and survival.

The two predominant causes of autonomous aldosterone secretion are aldosterone-producing adenomas (APA), treated by adrenalectomy, and idiopathic hyperaldosteronism, currently managed by chronic mineralocorticoid antagonist therapy. Despite progress in the management of PA patients, critical issues related to diagnosis, subtype differentiation, and treatment of not surgically correctable forms still persist. To date, the definitive diagnosis of $\mathrm{PA}$ is a multistep procedure requiring expert knowledge. For example, while adrenal venous sampling is recommended to assess whether aldosterone hypersecretion is lateralized in PA patients (19), this procedure is invasive, poorly standardized, and not widely available $(20,21)$. Overall, compared with its importance as the major secondary cause of hypertension, the currently available tools for diagnosis 
and treatment of PA are cumbersome and quite inefficient. These shortcomings relate in part to the heterogeneity of Conn's syndrome. In epidemiological terms, there appears to be a continuous spectrum from low renin hypertension, normokalemic Conn's syndrome to hypokalemic PA that makes cutoffs used for screening arbitrary. Likewise, based on histopathology of adrenal tissues resected because of unilateral PA, heterogeneity exists at multiple levels: aldosterone excess may be caused by micro- or macronodular hyperplasia or by typical adrenal adenoma (22); the adjacent adrenal cortex may be atrophic, diffuse hyperplastic, or nodular hyperplastic (23).

\section{Physiology of aldosterone regulation}

Until recently, functional data on the regulation of aldosterone secretion in rodent models had been scarce. This shortcoming had been at least in part due to the high sample volumes necessary for available commercial assays and by the lack of sensitivity to detect the very low concentrations of aldosterone. To improve this situation, we had developed a highly sensitive and non-isotopic, time-resolved fluorescence, competitive immunoassay that requires only a small sample volume for a duplicate measurement (24). Using a multiplex immunoassay technology, we could also demonstrate the feasibility of simultaneous measurement of steroid hormones in rodents (25). It is to be expected that steroid profiling by tandem mass spectrometry will further improve the determination of adrenal phenotypes in animal models $(26,27)$.

Following these technical requirements, we studied in detail normal aldosterone values of not only male and female animals of two common mouse strains, the $\mathrm{C} 3 \mathrm{HeB} / \mathrm{FeJ}$ and the $\mathrm{C} 57 \mathrm{BL} / 6$, but also all offspring after crossbreeding of these strains (F1 and F2 generations) (28). This investigation identified C57BL/6 animals with significantly higher values than those of $\mathrm{C} 3 \mathrm{HeB} / \mathrm{FeJ}$ mice. Interestingly, aldosterone levels in offspring animals were also different in dependence of maternally or paternally conferred phenotype, providing indirect evidence for epigenetic mechanisms that modulate baseline aldosterone release. Likewise, it has been demonstrated that RAAS components can be a target of epigenetic modifications such as $\mathrm{AT}(1 \mathrm{~b})$ angiotensin receptor gene expression, which is highly dependent on promoter methylation (29). Therefore, these mechanisms could contribute to hyperaldosteronism and development of hypertension also in the adult organism.

The storage capacity for aldosterone within the adrenal zona glomerulosa cell is very limited. Therefore, tight regulation of steroidogenesis from cholesterol is required to maintain the organism's fluid and electrolyte homeostasis (30). Within this process, transcriptional activation as well as posttranscriptional modification of steroidogenic enzymes are the major regulatory mechanisms for acute and chronic adrenocortical steroid production and release (31). The major rate-limiting steps for the synthesis of aldosterone are twofold: first, cholesterol needs to be transported to the inner mitochondrial membrane by the StAR protein (STAR) $(32,33)$ and secondly, conversion of 11-deoxycorticosterone to aldosterone is required by aldosterone synthase (34). Expression of CYP11B2 that encodes aldosterone synthase is mainly regulated by extracellular potassium concentration as well as angiotensin II. Already, very subtle changes in extracellular potassium $(35,36)$ set off a signaling cascade that is initiated by calcium influx through T- and L-type channels. Likewise, angiotensin II increases intracellular calcium content through calcium release from intracellular stores $(37,38)$. Through the calciumbinding protein, calmodulin increases in intracellular calcium activates calcium/calmodulin-dependent protein kinase I and IV (CaMK I/IV) (39), which translates in the activation of a number of transcription factors such as NURR1 (NR4A2), NGFIB (NR4A1), $A T F 1$, and CREB (CREB1) (30, 40). These transcription factors in turn activate promoter sites of the CYP11B2 gene and increase transcription of aldosterone synthase $(30,41)$. While these transcriptional-based mechanisms had initially been reported in the context of chronic stimulation experiments in a time frame of hours to days (41, 42), we could demonstrate that in vivo adrenal CYP11B2 expression is upregulated even within minutes upon specific stimulation experiments (43). As activation of CaMK-dependent pathways is detectable in Conn's adenomas (44), it is prudent to expect that these pathways also play a pathophysiological role in autonomous aldosterone secretion.

In addition to these well-defined molecular pathways, we could recently demonstrate that potassium challenge of experimental animals induces a whole array of transcriptional changes in the adrenal cortex (45). Upon in vitro verification of transcriptional regulation of some candidate genes, we further investigated the expression pattern in Conn's adenomas. Up to this point, the available information on the candidate genes in relation to adrenal physiology is limited: LPHN3 had been reported to be highly expressed in fetal as in adult adrenal glands (46). Another of the candidate genes, SPP1, coding for secreted phosphoprotein 1 had been identified in a meta-analysis of genome-wide gene expression analysis as a gene with lower expression during development of hypertension (47). As SPP1 was also found to be expressed less in Conn's adenomas, these findings might point toward a functional relevance of SPP1 in the pathophysiology of hypertension. While shortcomings of experimental models clearly have to be taken into account, the definition of candidate genes can serve as the starting point for further functional and translational studies. 


\section{Mouse models of PA}

\section{Potassium channels}

As alluded earlier, the particular relevance of calciumdependent signaling within the zona glomerulosa cell for the regulation of aldosterone secretion has long been appreciated (48). However, the functional significance of these molecular findings for PA only became clear when mouse models with targeted gene deletions affecting electrophysiological properties and intracellular $\mathrm{Ca}^{++}$content of glomerulosa cells were evidently affected by autonomous aldosterone secretion $(49,50)$. A number of $\mathrm{K}^{+}$channels of the 2-pore domain (K2P) family are expressed in zona glomerulosa cells including TREK1, TASK1, and TASK3. In rodents, only TASK1 and TASK3 appear to be major determinants of the membrane potential of adrenal glomerulosa cells. In keeping with this notion, knockout of Task1 alone or in combination with Task3 (Kcnk9) resulted in severe sex-dependent hyperaldosteronism that was restricted to female animals. Elevation of aldosterone secretion and concomitant low renin activity could not be normalized by changes in salt intake. As a consequence of PA, female Task1 knockout mice developed arterial hypertension and hypokalemia that could be normalized by blockade of the mineralocorticoid receptor with canrenoate $(49,50)$. Interestingly, on a morphological level, adrenals from Task1 knockout animals were characterized by an ectopic expression of Cyp $11 b 2$ within the zona fasciculata. Accordingly, some extent of ACTH dependency of aldosterone secretion could be demonstrated. While deletion of Task 3 in knockout mice also resulted in some level of aldosterone autonomy, the effects were found to be milder rather resembling those found in patients with low renin hypertension $(51,52)$. Taken together, these findings clearly point out that potassium channels have an impact on aldosterone secretion and can further affect adrenocortical zonation. Furthermore, the reports highlight that gender-dependent differences in phenotypic penetrance have to be taken into account in this pathophysiological scenario.

\section{Circadian clock genes}

Phenotypic characterization of mice lacking the core clock components cryptochrome-1 (Cry1) and Cry 2 (Cry-null mice) revealed the presence of salt-sensitive hypertension (53). CRY proteins act as potent transcriptional repressors that downregulate transcription of E-box enhancer-containing clock genes as well as a wide variety of clock-controlled targets. In Cry-null mice, autonomous aldosterone secretion was associated with chronic overexpression of Hsd3b6 within the adrenal cortex. This particular isoform of $\mathrm{Hsd} 3$ was found to be exclusively expressed in the zona glomerulosa and its overexpression to result in high aldosterone secretion and elevated blood pressure that was inducible by high salt intake and suppressible by mineralocorticoid receptor blockage. The human equivalent of the murine Hsd3b6, HSD 3B1, also displayed a glomerulosa specificity of expression providing indirect evidence for a functional significance for aldosterone secretion. So far, no evidence for transcriptional dysregulation of CRY genes or HSD3B1 in APA has been published. However, recently it was demonstrated that with a constant daily salt intake $\mathrm{Na}^{+}$ excretion exhibits aldosterone-dependent weekly rhythms, resulting in periodic changes in $\mathrm{Na}^{+}$storage (54). Therefore, it is possible that circadian clock generelated effects within the adrenal gland could also affect aldosterone secretion in humans and disruption of this system could be involved in the molecular mechanisms underlying, for example, the bilateral form of PA.

\section{Mutagenesis screen}

An approach to develop new mouse models for a specific phenotype is to induce genetic variation by random mutagenesis of the mouse genome using $\mathrm{N}$-ethyl- $\mathrm{N}$ nitrosourea (ENU) as the mutagen (55). ENU is an alkylating agent that causes ethylation of nucleic acids that ultimately result in point mutations. Specifically, ENU exerts mutagenic action on DNA of pre-meiotic spermatogonial stem cells (56), i.e. A-T base pair substitutions and/or small intragenic lesions. Many of the mutant offspring produced by ENU-treated mice will, therefore, be hypomorph (partial loss of function), although gain-of-function as well as complete lossof-function mutants can also be expected $(57,58)$. Several studies have demonstrated that the number of induced mutations depends on the dosage of ENU administered $(59,60)$ and on the number of exons and length of coding sequences (61). In the case of phenotype-driven genetics, the genomic association is accomplished using common single nucleotide polymorphisms (SNPs).

Following definition of normal values of aldosterone in wild-type mice (28), we established a mutagenesis screen for the parameter aldosterone. $\mathrm{C} 3 \mathrm{HeB} / \mathrm{FeJ}$ male animals were treated with three injections of ENU causing random point mutations in the genome. These animals were then mated to untreated female animals and all the F1 offspring were screened for their aldosterone levels. Animals that showed increased plasma aldosterone upon repeated measurement underwent further breeding. Therefore, these founders gave rise to $\mathrm{F} 2$ pedigrees from which eight lines with different patterns of inheritance of hyperaldosteronism could be established (62). Phenotypic characterization of unselected offspring of ENU-treated animals demonstrated elevation of aldosterone:renin ratio and lower potassium levels in affected animals in a gender-dependent manner. These biochemical changes were associated with higher adrenal expression of Cyp11b2 and 
increased zona glomerulosa area, indicating a phenotype of glomerulosa hyperplasia. Ongoing research aims at the identification of the underlying genetic event through SNP analysis of F2 pedigrees and exome sequencing of affected inbred animals.

\section{Genetic studies on PA in patient populations}

\section{PA patient registries}

An example for a national registry dedicated to the study of PA is the German multicenter Conn's registry (www.conn-register.de). Since its inauguration in 2006 within the prospective part of the registry, detailed clinical data and high-quality biosamples for genetic, metabolic, and steroid analysis have been generated. By now, 550 patients have been enrolled, and annual recruitment is currently around 100 new patients. Based on the annotation of this cohort, a number of clinically relevant questions could be addressed including prevalence of cardiovascular (63) or renal (64) comorbidities, improvement of diagnostic algorithms $(65,66)$, and description of long-term outcome of PA patients (67). As the European equivalent, the European Network for the Study of Adrenal Tumors (ENS@T, www.ensat.org) has set up a registry and associated biobank and aims to improve the understanding of the genetics, tumorigenesis, and hypersecretion in patients with adrenal tumors and associated familial syndromes $(68,69)$. The funding by the European Science Foundation (www.ensat.org/ esfensat.html) and by the European Community (www.ensat-cancer.eu) has allowed the implementation of a European database and also biobanking for PA (70), with the German Conn's registry being one of the major contributors.

\section{Genome-wide association studies}

Similar to investigations in inbred mouse strains (71) in population-based studies, the aldosterone-torenin ratio has been recognized as an inherited trait and predictor of increased blood pressure $(72,73)$. Technological advances in human genomics now allow the study of a large entity of the allelic spectrum from the frequent to the very rare inherited or de novo genetic variants. Genome-wide association studies (GWAS) are powerful to identify common genetic susceptibility loci in human heredity and disease. GWAS uses genotyping arrays of a dense set of common SNPs to generate genotypes in large populations of cases and controls (74). This method has greatly improved our knowledge about human genetics, especially for common diseases, where both genetic and environmental factors contribute to disease susceptibility (75). In fact, in a recent GWAS, systolic and diastolic blood pressure could be correlated with 16 novel genetic loci (76). It is to be expected that this method - when applied to large enough and wellcharacterized patient cohorts - will also contribute to the elucidation of genetic events resulting in idiopathic bilateral hyperplasia.

\section{Identification of candidate genes by exome sequencing}

Despite its high prevalence, so far, the genetic causes of PA have been elucidated only for the rare familial forms of the disease. Worldwide, only a few families have been identified with familial hyperaldosteronism $(\mathrm{FH})$ type 1 , also known as glucocorticoid-remediable hyperaldosteronism (77). The condition reflects the presence of a hybrid gene resulting from unequal crossing over between the highly homologous genes CYP11B2 and CYP11B1, coding for aldosterone synthase and steroid $11 \beta$-hydroxylase (77). This fusion produces a chimeric gene, with activity of aldosterone synthase, but tissue specificity and regulation of $11 \beta$-hydroxylase, so that the synthesis of aldosterone is under control of ACTH rather than plasma potassium concentrations and the renin-angiotensin system.

FH2 summarizes several forms of genetically determined PA. Likewise, the morphological and functional phenotype is variable from APA to bilateral hyperplasia. A locus has been mapped on chromosome 7 p22 in some but not all families (78), but the linkage area has not been resolved to any causative mutation.

KCNJ5 Next-generation sequencing applies massively parallel sequencing of clonally amplified or single-DNA molecules that are spatially separated in a flow cell. This design has allowed scaling-up of sequencing by orders of magnitude and has been used to identify mutations in the context of inherited disorders, complex human diseases, and cancer research among others (79). As benign tumors such as APAs are considered genomically stable, only a low number of somatic mutations have to be expected, further increasing the likelihood of identifying functionally relevant genetic alterations. As exemplified by the identification of KCNJ5 mutations in APAs, exome sequencing is a powerful tool to reveal point mutations in genes that would not have necessarily been detected within a candidate gene-driven approach (80).

KCNJ5 encodes the $\mathrm{G}$ protein-activated inward rectifier potassium channel GIRK4. In parallel with the elucidation of $\mathrm{FH} 3$, the recent detection of KCNJ5 point mutations in sporadic APAs has been a major scientific breakthrough (81). The different hot spot mutations identified in APA (p.G151R and p.L168R) and FH-3 (p.T158A) are clustered near or within the selectivity filter of GIRK4 and affect the ion selectivity of the channel, with increased sodium conductance leading to chronic membrane depolarization (Fig. 1). 
(a)

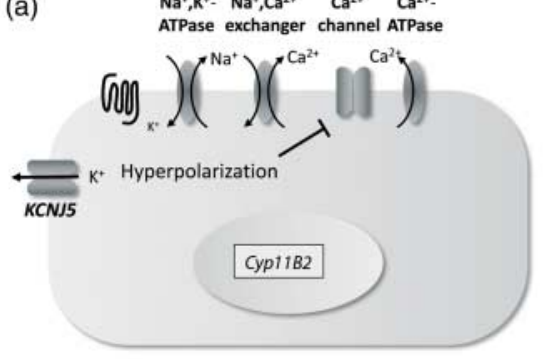

(c)

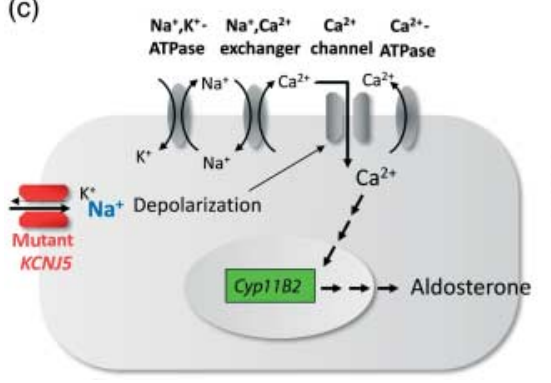

(1)

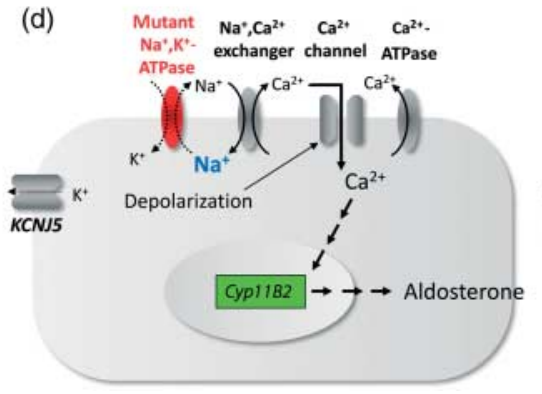

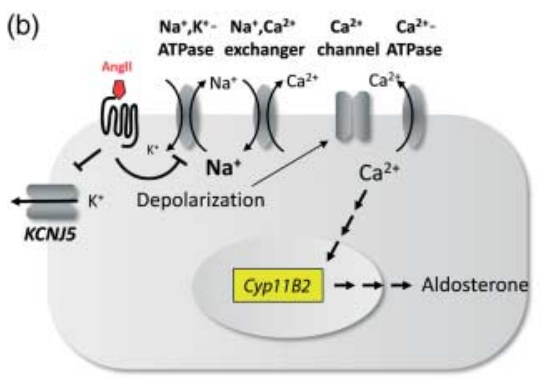

(e)

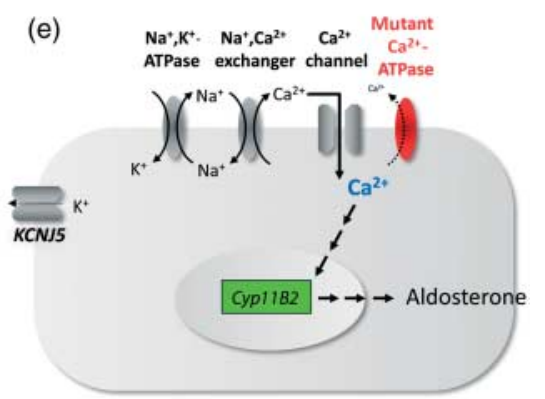

Figure 1 Schematic model of normal aldosterone regulation and genetic abnormalities leading to autonomous aldosterone secretion. (a) In the normal adrenal gland, potassium channels, calcium channels, and ATPases are involved in maintaining the hyperpolarized state of the glomerulosa cell membrane. (b) Among other stimuli, angiotensin 2 acts in part by inhibiting function or expression of potassium channels and $\mathrm{Na}^{+}, \mathrm{K}^{+}$-ATPase, which results in cell membrane depolarization, opening of voltage-gated Ca ${ }^{++}$channels, and activation of calcium signaling, the main trigger for increase in Cyp11B2 expression and aldosterone production. Mutations in KCNJ5 (c) and ATP1A1 (d) result in inappropriate depolarization of glomerulosa cells, while mutations in ATP2B3 (encoding the Ca ${ }^{++}$-ATPase) (e) are predicted to lead to elevation of intracellular $\mathrm{Ca}^{++}$through abnormal calcium recycling.

These changes are responsible for increased calcium influx into the cell leading to constitutive secretion of aldosterone and possibly cell proliferation $(80,82)$. Since its first publication, large collections of sporadic APAs have been screened worldwide demonstrating with one exception (83) - that KCNJ5 mutations are present in 34-65\% of APAs (for references, see Table 1).

Notably, KCNJ5 mutations appear to be isolated events in the progression toward APA, as they were not identified within the adjacent adrenal cortex of an APA carrying a mutation. These findings are in line with the concept that KCNJ5 mutations may occur within a proliferating and hyperplastic cortex, leading to growth advantage, clonal expansion, and APA formation in a considerable number of cases. Transcriptome analysis performed on a large number of APA samples showed that KCNJ5 mutations were not associated with a unique molecular signature, as could have been expected from mutations acting on key signaling pathways or master transcriptional regulators (81). Rather, they may represent one of several possible mechanisms triggering, via increased $\mathrm{Ca}^{2+}$ signaling and/or other pathways, increased cell proliferation, and aldosterone production.

ATP1A1 and ATP2B3 We recently set out to identify additional genetic causes of autonomous aldosterone secretion. To achieve this goal, we implemented exome sequencing in APA and matched control tissue from nine male patients that were characterized by hypokalemic PA and did not possess somatic KCNJ5 mutations (84). Within this small patient group, we identified somatic mutations in two genes that had not yet been related to PA: ATP1A1, coding for the $\alpha$ subunit of the $\mathrm{Na}^{+}, \mathrm{K}^{+}$-ATPase; and ATP2B3, coding for the plasma membrane calcium-transporting ATPase 3 (PMCA3). The identified mutations affected highly conserved regions within the proteins required for direct interaction with transported potassium for $\mathrm{Na}^{+}, \mathrm{K}^{+}$ -ATPase and calcium for PMCA3 (Fig. 1). In vitro studies showed that the identified ATP1A1 mutations

Table 1 Prevalence of somatic KCNJ5 mutations in aldosteroneproducing adenomas.

\begin{tabular}{|c|c|c|c|}
\hline References & $n$ & $\begin{array}{l}\text { KCNJ5-mutated } \\
\text { tumors (\%) }\end{array}$ & $\begin{array}{l}\text { Special clinical } \\
\text { features }\end{array}$ \\
\hline (81) & 380 & 34 & $\begin{array}{l}\text { Preferentially females; } \\
\text { lower age }\end{array}$ \\
\hline (85) & 351 & 47 & $\begin{array}{l}\text { Preferentially females; } \\
\text { larger tumors }\end{array}$ \\
\hline (86) & 73 & 41 & $\begin{array}{l}\text { Lager tumors, lack of } \\
\text { postural aldosterone } \\
\text { response }\end{array}$ \\
\hline (83) & 53 & 2 & - \\
\hline (87) & 47 & 38 & - \\
\hline (88) & 46 & 43 & $\begin{array}{l}\text { Tumors larger, lower } \\
\text { age }\end{array}$ \\
\hline (89) & 23 & 65 & - \\
\hline Total & 973 & 38.8 & \\
\hline
\end{tabular}


significantly reduced the physiological $\mathrm{Na}^{+}, \mathrm{K}^{+}$-pump activity, as well as the apparent affinity of $\mathrm{Na}^{+}, \mathrm{K}^{+}$ -ATPase for $\mathrm{K}^{+}$. In ex vivo experiments, electrophysiological measurements on primary cultured adenoma cells with different ATP1A1 mutations revealed inappropriate depolarization of cells with ATPase mutations. Given the highly specific position of mutations identified in both genes, a gain-of-function mechanism would be predicted from a genetic point of view. Based on the in vitro and ex vivo results, deleterious impact of the identified mutation on the pump activity of the $\mathrm{Na}^{+}, \mathrm{K}^{+}$-ATPase enzyme is evident. However, it is conceivable that similar to the mechanisms observed for $\mathrm{KCNJ} 5$, the mutations could, in addition, result in cation leakage of the affected ATPases, followed by cellular depolarization. As overexpression of mutated ATPases is toxic in most cellular systems, this hypothesis needs to be further tested in appropriate models.

In a large collection of 309 APA samples, we demonstrated that somatic ATP1A1 mutations were present in $5.2 \%$ and ATP $2 B 3$ mutations in $1.6 \%$ of patients. We were not able to identify germline mutations in ATP1A1 or ATP2B3 in patients with $\mathrm{FH}$ or with the sporadic bilateral form of the disease. Both $\mathrm{Na}^{+}, \mathrm{K}^{+}$-ATPase and $\mathrm{Ca}^{2+}$-ATPase are required for a multitude of vital cellular processes that rely on the generation of electrochemical gradients. Therefore, it is to be expected that mutations in these genes would not be compatible with life, which explains the lack of systemic mutations.

No Conn adenoma was identified that carried both KCNJ5 and ATPase mutations, providing indirect evidence that either mutation is sufficient to bring about the clinical phenotype. Although mutation carriers showed increased plasma aldosterone and lower potassium compared with non-carriers, similar to what has been observed in KCNJ5 mutation carriers, ATPase mutations displayed male dominance. Consistent with a more severe phenotype, carriers of ATPasemutated tumors had higher preoperative aldosterone levels and significantly lower serum potassium concentrations. In contrast, other clinical features such as blood pressure, tumor size, and urine albumin secretion among others were not different between the groups.

Taken together, these findings highlight the power of high-throughput techniques that are able to identify new genetic mechanisms involved in PA. In addition to the mechanistic insights, these findings might hold the promise for potential therapeutic targets as well as novel biomarkers that could aid in personalized treatment decisions.

\section{Conclusion}

The last years have witnessed the elucidation of molecular and genetic mechanisms that ultimately result in autonomous aldosterone secretion and PA.
A number of rodent models with a PA phenotype could be added to the experimental armamentarium for future functional and interventional studies. In parallel, a new form of FH could be elucidated and an increasing proportion of Conn's adenomas could be attributed to specific somatic genetic alterations. This development opens up entirely different areas of research, which might ultimately lead to new biomarkers and molecularly targeted treatment for PA patients. It is to be expected that further candidate genes will be identified in patients with type II FH as well as in sporadic APA.

\section{Declaration of interest}

The author declares that there is no conflict of interest that could be perceived as prejudicing the impartiality of the review reported.

\section{Funding}

This work was supported in part by the Deutsche Forschungsgemeinschaft (Re 752/17-1).

\section{References}

1 Egan BM, Zhao Y \& Axon RN. US trends in prevalence, awareness, treatment, and control of hypertension, 1988-2008. Journal of the American Medical Association 2010303 2043-2050. (doi:10.1001/jama.2010.650)

2 Labeit AM, Klotsche J, Pieper L, Pittrow D, Einsle F, Stalla GK, Lehnert H, Silber S, Zeiher AM, Marz W et al. Changes in the prevalence, treatment and control of hypertension in Germany? A clinical-epidemiological study of 50.000 primary care patients PLoS ONE 20127 e52229. (doi:10.1371/journal.pone.0052229)

3 Ferrario CM. Role of angiotensin II in cardiovascular disease therapeutic implications of more than a century of research. Journal of Renin-Angiotensin-Aldosterone System 20067 3-14. (doi:10.3317/jraas.2006.003)

4 Brewster UC, Setaro JF \& Perazella MA. The renin-angiotensinaldosterone system: cardiorenal effects and implications for renal and cardiovascular disease states. American Journal of the Medical Sciences 2003326 15-24. (doi:10.1097/00000441200307000-00003)

5 Cooper ME. The role of the renin-angiotensin-aldosterone system in diabetes and its vascular complications. American Journal of Hypertension 200417 16S-20S quiz (A12-A14). (doi:10.1016/ j.amjhyper.2004.08.004)

6 Vasan RS, Evans JC, Larson MG, Wilson PW, Meigs JB, Rifai N, Benjamin EJ \& Levy D. Serum aldosterone and the incidence of hypertension in nonhypertensive persons. New England Journal of Medicine 2004351 33-41. (doi:10.1056/NEJMoa033263)

7 Tsutamoto T, Sakai H, Tanaka T, Fujii M, Yamamoto T, Wada A, Ohnishi M \& Horie M. Comparison of active renin concentration and plasma renin activity as a prognostic predictor in patients with heart failure. Circulation Journal 200771 915-921. (doi:10.1253/ circj.71.915)

8 Guder G, Bauersachs J, Frantz S, Weismann D, Allolio B, Ertl G, Angermann CE \& Stork S. Complementary and incremental mortality risk prediction by cortisol and aldosterone in chronic heart failure. Circulation 2007115 1754-1761. (doi:10.1161/ CIRCULATIONAHA.106.653964)

9 Beygui F, Collet JP, Benoliel JJ, Vignolles N, Dumaine R, Barthelemy O \& Montalescot G. High plasma aldosterone levels on admission are associated with death in patients presenting with acute ST-elevation myocardial infarction. Circulation 2006114 2604-2610. (doi:10.1161/CIRCULATIONAHA.106.634626) 
10 Tylicki L, Larczynski W \& Rutkowski B. Renal protective effects of the renin-angiotensin-aldosterone system blockade: from evidence-based approach to perspectives. Kidney $\mathcal{E}$ Blood Pressure Research 200528 230-242. (doi:10.1159/000087842)

11 Hannemann A, Friedrich N, Ludemann J, Volzke H, Rettig R, Peters J, Reincke M, Doring A, Nauck M \& Wallaschofski H. Reference intervals for aldosterone, renin, and the aldosterone-to-renin ratio in the population-based Study of Health in Pomerania (SHIP-1). Hormone and Metabolic Research 201042 392-399. (doi:10.1055/ s-0030-1247545)

12 Calhoun DA, Nishizaka MK, Zaman MA, Thakkar RB \& Weissmann P. Hyperaldosteronism among black and white subjects with resistant hypertension. Hypertension $2002 \mathbf{4 0}$ 892-896. (doi:10.1161/01.HYP.0000040261.30455.B6)

13 Douma S, Petidis K, Doumas M, Papaefthimiou P, Triantafyllou A, Kartali N, Papadopoulos N, Vogiatzis K \& Zamboulis C. Prevalence of primary hyperaldosteronism in resistant hypertension: a retrospective observational study. Lancet 2008371 1921-1926. (doi:10.1016/S0140-6736(08)60834-X)

14 Funder JW \& Reincke M. Aldosterone: a cardiovascular risk factor? Biochimica et Biophysica Acta $2010 \mathbf{1 8 0 2} 1188-1192$. (doi:10.1016/j.bbadis.2010.08.005)

15 Milliez P, Girerd X, Plouin PF, Blacher J, Safar ME \& Mourad JJ. Evidence for an increased rate of cardiovascular events in patients with primary aldosteronism. Journal of the American College of Cardiology 200545 1243-1248. (doi:10.1016/j.jacc. 2005.01.015)

16 Catena C, Colussi G, Nadalini E, Chiuch A, Baroselli S, Lapenna R \& Sechi LA. Cardiovascular outcomes in patients with primary aldosteronism after treatment. Archives of Internal Medicine 2008 168 80-85. (doi:10.1001/archinternmed.2007.33)

17 Sechi LA, Colussi G, Di Fabio A \& Catena C. Cardiovascular and renal damage in primary aldosteronism: outcomes after treatment. American Journal of Hypertension 201023 1253-1260. (doi:10.1038/ajh.2010.169)

18 Rossi GP, Bernini G, Desideri G, Fabris B, Ferri C, Giacchetti G, Letizia C, Maccario M, Mannelli M, Matterello MJ et al. Renal damage in primary aldosteronism: results of the PAPY Study. Hypertension $2006 \mathbf{4 8}$ 232-238. (doi:10.1161/01.HYP. 0000230444.01215.6a)

19 Funder J, Carey R, Fardella C, Gomez-Sanchez C, Mantero F, Stowasser M, Young W \& Montori VM. Case detection, diagnosis, and treatment of patients with primary aldosteronism: an Endocrine Society Clinical Practice Guideline. European Journal of Endocrinology 200993 3266-3281. (doi:10.1530/EJE-09-0870)

20 Rossi GP, Barisa M, Allolio B, Auchus RJ, Amar L, Cohen D, Degenhart C, Deinum J, Fischer E, Gordon R et al. The Adrenal Vein Sampling International Study (AVIS) for identifying the major subtypes of primary aldosteronism. Journal of Clinica Endocrinology and Metabolism 201297 1606-1614. (doi:10. 1210/jc.2011-2830)

21 Stewart PM \& Allolio B. Adrenal vein sampling for primary aldosteronism: time for a reality check. Clinical Endocrinology 2010 72 146-148. (doi:10.1111/j.1365-2265.2009.03714.x)

22 Gomez-Sanchez CE, Rossi GP, Fallo F \& Mannelli M. Progress in primary aldosteronism: present challenges and perspectives. Hormone and Metabolic Research 2010 42 374-381. (doi:10.1055/ s-0029-1243619)

23 Boulkroun S, Samson-Couterie B, Dzib JF, Lefebvre H, Louiset E, Amar L, Plouin PF, Lalli E, Jeunemaitre X, Benecke A et al. Adrenal cortex remodeling and functional zona glomerulosa hyperplasia in primary aldosteronism. Hypertension $2010 \quad \mathbf{5 6} \quad 885-892$. (doi:10.1161/HYPERTENSIONAHA.110.158543)

24 Manolopoulou J, Bielohuby M, Caton SJ, Gomez-Sanchez CE, Renner-Mueller I, Wolf E, Lichtenauer UD, Beuschlein F, Hoeflich A \& Bidlingmaier M. A highly sensitive immunofluorometric assay for the measurement of aldosterone in small sample volumes: validation in mouse serum. Journal of Endocrinology 2008196 215-224. (doi:10.1677/JOE-07-0134)

25 Sun M, Manolopoulou J, Spyroglou A, Beuschlein F, Hantel C, Wu Z, Bielohuby M, Hoeflich A, Liu C \& Bidlingmaier M. A microsphere-based duplex competitive immunoassay for the simultaneous measurements of aldosterone and testosterone in small sample volumes: validation in human and mouse plasma. Steroids 201075 1089-1096. (doi:10.1016/j.steroids. 2010.07.005)

26 Johnsen IK, Slawik M, Shapiro I, Hartmann MF, Wudy SA, Looyenga BD, Hammer GD, Reincke M \& Beuschlein F. Gonadectomy in mice of the inbred strain $\mathrm{CE} / \mathrm{J}$ induces proliferation of sub-capsular adrenal cells expressing gonadal marker genes. Journal of Endocrinology 2006190 47-57. (doi:10.1677/joe.1. 06750)

27 Haller F, Prehn C \& Adamski J. Quantification of steroids in human and mouse plasma using online solid phase extraction coupled to liquid chromatography tandem mass spectrometry. Nature 2010. (doi:10.1038/nprot.2010.22)

28 Spyroglou A, Sabrautzki S, Rathkolb B, Bozoglu T, Hrabe de Angelis M, Reincke M, Bidlingmaier M \& Beuschlein F. Gender, strain and inheritance dependent variation in aldosterone secretion in mice. Journal of Endocrinology 2012215 375-381. (doi:10.1530/JOE-12-0429)

29 Bogdarina I, Welham S, King PJ, Burns SP \& Clark AJ. Epigenetic modification of the renin-angiotensin system in the fetal programming of hypertension. Circulation Research $2007 \mathbf{1 0 0}$ 520-526. (doi:10.1161/01.RES.0000258855.60637.58)

30 Bassett MH, White PC \& Rainey WE. The regulation of aldosterone synthase expression. Molecular and Cellular Endocrinology 2004 217 67-74. (doi:10.1016/j.mce.2003.10.011)

31 Christenson LK \& Strauss JF III. Steroidogenic acute regulatory protein: an update on its regulation and mechanism of action. Archives of Medical Research 200132 576-586. (doi:10.1016/ S0188-4409(01)00338-1)

32 Lin D, Sugawara T, Strauss JF III, Clark BJ, Stocco DM, Saenger P, Rogol A \& Miller WL. Role of steroidogenic acute regulatory protein in adrenal and gonadal steroidogenesis. Science $1995 \mathbf{2 6 7}$ 1828-1831. (doi:10.1126/science.7892608)

33 Cherradi N, Brandenburger Y \& Capponi AM. Mitochondrial regulation of mineralocorticoid biosynthesis by calcium and the StAR protein. European Journal of Endocrinology $1998 \mathbf{1 3 9}$ 249-256. (doi:10.1530/eje.0.1390249)

34 Curnow KM, Tusie-Luna MT, Pascoe L, Natarajan R, Gu JL, Nadler JL \& White PC. The product of the CYP11B2 gene is required for aldosterone biosynthesis in the human adrenal cortex. Molecular Endocrinology 19915 1513-1522. (doi:10. 1210/mend-5-10-1513)

35 Boyd JE \& Mulrow PJ. Further studies of the influence of potassium upon aldosterone production in the rat. Endocrinology 197290 299-301. (doi:10.1210/endo-90-1-299)

36 Varnai P, Petheo GL, Makara JK \& Spat A. Electrophysiological study on the high $\mathrm{K}^{+}$sensitivity of rat glomerulosa cells. Pflügers Archiv: European Journal of Physiology $1998 \mathbf{4 3 5}$ 429-431. (doi:10.1007/s004240050534)

37 Akizuki O, Inayoshi A, Kitayama T, Yao K, Shirakura S, Sasaki K, Kusaka H \& Matsubara M. Blockade of T-type voltage-dependent $\mathrm{Ca}^{2+}$ channels by benidipine, a dihydropyridine calcium channel blocker, inhibits aldosterone production in human adrenocortical cell line NCI-H295R. European Journal of Pharmacology $2008 \mathbf{5 8 4}$ 424-434. (doi:10.1016/j.ejphar.2008.02.001)

38 Lotshaw DP. Role of membrane depolarization and T-type $\mathrm{Ca}^{2+}$ channels in angiotensin II and $\mathrm{K}^{+}$stimulated aldosterone secretion. Molecular and Cellular Endocrinology 2001175 157171. (doi:10.1016/S0303-7207(01)00384-7)

39 Condon JC, Pezzi V, Drummond BM, Yin S \& Rainey WE. Calmodulin-dependent kinase I regulates adrenal cell expression of aldosterone synthase. Endocrinology 2002143 3651-3657. (doi:10.1210/en.2001-211359)

40 Bassett MH, Suzuki T, Sasano H, White PC \& Rainey WE. The orphan nuclear receptors NURR1 and NGFIB regulate adrenal aldosterone production. Molecular Endocrinology $2004 \mathbf{1 8}$ 279-290. (doi:10.1210/me.2003-0005) 
41 Clyne CD, Zhang Y, Slutsker L, Mathis JM, White PC \& Rainey WE. Angiotensin II and potassium regulate human CYP11B2 transcription through common cis-elements. Molecular Endocrinology 199711 638-649. (doi:10.1210/me.11.5.638)

42 Denner K, Rainey WE, Pezzi V, Bird IM, Bernhardt R \& Mathis JM. Differential regulation of 11ß-hydroxylase and aldosterone synthase in human adrenocortical H295R cells. Molecular and Cellular Endocrinology 1996121 87-91. (doi:10.1016/03037207(96)03853-1)

43 Spyroglou A, Manolopoulou J, Wagner S, Bidlingmaier M, Reincke M \& Beuschlein F. Short term regulation of aldosterone secretion after stimulation and suppression experiments in mice. Journal of Molecular Endocrinology 200942 407-413. (doi:10.1677/JME-08-0167)

44 Sackmann S, Lichtenauer U, Shapiro I, Reincke M \& Beuschlein F. Aldosterone producing adrenal adenomas are characterized by activation of calcium/calmodulin-dependent protein kinase (CaMK) dependent pathways. Hormone and Metabolic Research 201143 106-111. (doi:10.1055/s-0030-1269899)

45 Dierks A, Lichtenauer UD, Sackmann S, Spyroglou A, Shapiro I, Geyer M, Manonopoulou J, Reincke M, Hantel C \& Beuschlein F. Identification of adrenal genes regulated in a potassiumdependent manner. Journal of Molecular Endocrinology 201045 193-206. (doi:10.1677/JME-09-0171)

46 Xing Y, Nakamura Y \& Rainey WE. G protein-coupled receptor expression in the adult and fetal adrenal glands. Molecular and Cellular Endocrinology 2009300 43-50. (doi:10.1016/j.mce. 2008.10.036)

47 Marques FZ, Campain AE, Yang YH \& Morris BJ. Meta-analysis of genome-wide gene expression differences in onset and maintenance phases of genetic hypertension. Hypertension $2010 \mathbf{5 6}$ 319-324. (doi:10.1161/HYPERTENSIONAHA.110.155366)

48 Spat A \& Hunyady L. Control of aldosterone secretion: a model for convergence in cellular signaling pathways. Physiological Reviews 200484 489-539. (doi:10.1152/physrev.00030.2003)

49 Heitzmann D, Derand R, Jungbauer S, Bandulik S, Sterner C, Schweda F, El Wakil A, Lalli E, Guy N, Mengual R et al. Invalidation of TASK1 potassium channels disrupts adrenal gland zonation and mineralocorticoid homeostasis. EMBO Journal $2008 \mathbf{2 7}$ 179-187. (doi:10.1038/sj.emboj.7601934)

50 Davies LA, Hu C, Guagliardo NA, Sen N, Chen X, Talley EM, Carey RM, Bayliss DA \& Barrett PQ. TASK channel deletion in mice causes primary hyperaldosteronism. PNAS $2008 \mathbf{1 0 5}$ 2203-2208. (doi:10.1073/pnas.0712000105)

51 Guagliardo NA, Yao J, Hu C, Schertz EM, Tyson DA, Carey RM, Bayliss DA \& Barrett PQ. TASK-3 channel deletion in mice recapitulates low-renin essential hypertension. Hypertension 2012 59 999-1005. (doi:10.1161/HYPERTENSIONAHA.111.189662)

52 Penton D, Bandulik S, Schweda F, Haubs S, Tauber P, Reichold M, Cong LD, El Wakil A, Budde T, Lesage F et al. Task3 potassium channel gene invalidation causes low renin and salt-sensitive arterial hypertension. Endocrinology 2012153 4740-4748. (doi:10.1210/en.2012-1527)

53 Doi M, Takahashi Y, Komatsu R, Yamazaki F, Yamada H, Haraguchi S, Emoto N, Okuno Y, Tsujimoto G, Kanematsu A et al. Salt-sensitive hypertension in circadian clock-deficient Cry-null mice involves dysregulated adrenal Hsd3b6. Nature Medicine 201016 67-74. (doi:10.1038/nm.2061)

54 Rakova N, Juttner K, Dahlmann A, Schroder A, Linz P, Kopp C, Rauh M, Goller U, Beck L, Agureev A et al. Long-term space flight simulation reveals infradian rhythmicity in human $\mathrm{Na}(+)$ balance. Cell Metabolism 201317 125-131. (doi:10.1016/ j.cmet.2012.11.013)

55 Clark AT, Goldowitz D, Takahashi JS, Vitaterna MH, Siepka SM, Peters LL, Frankel WN, Carlson GA, Rossant J, Nadeau JH et al. Implementing large-scale ENU mutagenesis screens in North America. Genetica 2004122 51-64. (doi:10.1007/s10709-0041436-6)

56 Rinchik EM. Chemical mutagenesis and fine-structure functional analysis of the mouse genome. Trends in Genetics 19917 15-21. (doi:10.1016/0168-9525(91)90016-J)
57 Noveroske JK, Weber JS \& Justice MJ. The mutagenic action of $N$-ethyl-N-nitrosourea in the mouse. Mammalian Genome 2000 11 478-483. (doi:10.1007/s003350010093)

58 Justice MJ, Carpenter DA, Favor J, Neuhauser-Klaus A, Hrabe de Angelis M, Soewarto D, Moser A, Cordes S, Miller D, Chapman V et al. Effects of ENU dosage on mouse strains. Mammalian Genome 200011 484-488. (doi:10.1007/s003350010094)

59 Coghill EL, Hugill A, Parkinson N, Davison C, Glenister P, Clements S, Hunter J, Cox RD \& Brown SD. A gene-driven approach to the identification of ENU mutants in the mouse. Nature Genetics 200230 255-256. (doi:10.1038/ng847)

60 Quwailid MM, Hugill A, Dear N, Vizor L, Wells S, Horner E, Fuller S, Weedon J, McMath H, Woodman P et al. A gene-driven ENU-based approach to generating an allelic series in any gene. Mammalian Genome 200415 585-591. (doi:10.1007/s00335004-2379-z)

61 Barbaric I, Wells S, Russ A \& Dear TN. Spectrum of ENUinduced mutations in phenotype-driven and gene-driven screens in the mouse. Environmental and Molecular Mutagenesis $2007 \mathbf{4 8}$ 124-142. (doi:10.1002/em.20286)

62 Spyroglou A, Wagner S, Gomez-Sanchez C, Rathkolb B, Wolf E, Manolopoulou J, Reincke M, Bidlingmaier M, Hrabe de Angelis M \& Beuschlein F. Utilization of a mutagenesis screen to generate mouse models of hyperaldosteronism. Endocrinology 2011152 326-331. (doi:10.1210/en.2010-1081)

63 Born-Frontsberg E, Reincke M, Rump LC, Hahner S, Diederich S, Lorenz R, Allolio B, Seufert J, Schirpenbach C, Beuschlein F et al. Cardiovascular and cerebrovascular comorbidities of hypokalemic and normokalemic primary aldosteronism: results of the German Conn's registry. Journal of Clinical Endocrinology and Metabolism 200994 1125-1130. (doi:10.1210/jc.2008-2116)

64 Reincke M, Rump LC, Quinkler M, Hahner S, Diederich S, Lorenz R, Seufert J, Schirpenbach C, Beuschlein F, Bidlingmaier $\mathrm{M}$ et al. Risk factors associated with a low glomerular filtration rate in primary aldosteronism. Journal of Clinical Endocrinology and Metabolism 200994 869-875. (doi:10.1210/ jc.2008-1851)

65 Betz MJ, Degenhart C, Fischer E, Pallauf A, Brand V, Linsenmaier U, Beuschlein F, Bidlingmaier $M$ \& Reincke $M$. Adrenal vein sampling using rapid cortisol assays in primary aldosteronism is useful in centers with low success rates. European Journal of Endocrinology 2011165 301-306. (doi:10.1530/EJE11-0287)

66 Vonend O, Ockenfels N, Gao X, Allolio B, Lang K, Mai K, Quack I, Saleh A, Degenhart C, Seufert J et al. Adrenal venous sampling: evaluation of the German Conn's registry. Hypertension 201157 990-995. (doi:10.1161/HYPERTENSIONAHA.110.168484)

67 Reincke M, Fischer E, Gerum S, Merkle K, Schulz S, Pallauf A, Quinkler M, Hanslik G, Lang K, Hahner S et al. Observational study mortality in treated primary aldosteronism: the German Conn's registry. Hypertension 201260 618-624. (doi:10.1161/ HYPERTENSIONAHA.112.197111)

68 Johnsen IK, Hahner S, Briere JJ, Ozimek A, Gimenez-Roqueplo AP, Hantel C, Adam P, Bertherat J \& Beuschlein F. Evaluation of a standardized protocol for processing adrenal tumor samples: preparation for a European Adrenal Tumor Bank. Hormone and Metabolic Research 201042 93-101. (doi:10.1055/s-00291241858)

69 Fassnacht M, Johanssen S, Quinkler M, Bucsky P, Willenberg HS, Beuschlein F, Terzolo M, Mueller HH, Hahner S \& Allolio B. Limited prognostic value of the 2004 International Union Against Cancer staging classification for adrenocortical carcinoma: proposal for a Revised TNM Classification. Cancer 2009115 243-250. (doi:10.1002/cncr.24030)

70 Stell A, Sinnott R \& Jiang J. Enabling secure, distributed collaborations for adrenal tumor research. Studies in Health Technology and Informatics 2010159 259-263.

71 Hannemann A, Bidlingmaier M, Friedrich N, Manolopoulou J, Spyroglou A, Volzke H, Beuschlein F, Seissler J, Rettig R, Felix SB et al. Screening for primary aldosteronism in 
hypertensive subjects: results from two German Epidemiological Studies. European Journal of Endocrinology $2012 \quad \mathbf{1 6 7}$ 7-15. (doi:10.1530/EJE-11-1013)

72 Newton-Cheh C, Guo CY, Gona P, Larson MG, Benjamin EJ, Wang TJ, Kathiresan S, O’Donnell CJ, Musone SL, Camargo AL et al. Clinical and genetic correlates of aldosterone-to-renin ratio and relations to blood pressure in a community sample. Hypertension 200749 846-856. (doi:10.1161/01.HYP.000025 $8554.87444 .91)$

73 Alvarez-Madrazo S, Padmanabhan S, Mayosi BM, Watkins H, Avery P, Wallace AM, Fraser R, Davies E, Keavney B \& Connell JM. Familial and phenotypic associations of the aldosterone Renin ratio. Journal of Clinical Endocrinology and Metabolism 200994 4324-4333. (doi:10.1210/jc.2009-1406)

74 Frazer KA, Ballinger DG, Cox DR, Hinds DA, Stuve LL, Gibbs RA, Belmont JW, Boudreau A, Hardenbol P, Leal SM et al. A second generation human haplotype map of over 3.1 million SNPs. Nature 2007449 851-861. (doi:10.1038/nature06258)

75 Hirschhorn JN \& Daly MJ. Genome-wide association studies for common diseases and complex traits. Nature Reviews. Genetics 20056 95-108. (doi:10.1038/nrg1521)

76 Ehret GB, Munroe PB, Rice KM, Bochud M, Johnson AD, Chasman DI, Smith AV, Tobin MD, Verwoert GC, Hwang SJ et al. Genetic variants in novel pathways influence blood pressure and cardiovascular disease risk. Nature $2011 \mathbf{4 7 8} 103-109$. (doi:10.1038/nature10405)

77 Lifton RP, Dluhy RG, Powers M, Rich GM, Cook S, Ulick S \& Lalouel JM. A chimaeric 11 $\beta$-hydroxylase/aldosterone synthase gene causes glucocorticoid-remediable aldosteronism and human hypertension. Nature 1992355 262-265. (doi:10.1038/ 355262a0)

78 Iida A, Blake K, Tunny T, Klemm S, Stowasser M, Hayward N, Gordon R, Nakamura Y \& Imai T. Allelic losses on chromosome band $11 \mathrm{q} 13$ in aldosterone-producing adrenal tumors. Genes, Chromosomes \& Cancer 199512 73-75. (doi:10.1002/gcc. 2870120114)

79 Pareek CS, Smoczynski R \& Tretyn A. Sequencing technologies and genome sequencing. Journal of Applied Genetics 2011 52 413-435. (doi:10.1007/s13353-011-0057-x)

80 Choi M, Scholl UI, Yue P, Bjorklund P, Zhao B, Nelson-Williams C, Ji W, Cho Y, Patel A, Men CJ et al. $\mathrm{K}^{+}$channel mutations in adrenal aldosterone-producing adenomas and hereditary hypertension. Science 2011331 768-772. (doi:10.1126/science.1198785)

81 Boulkroun S, Beuschlein F, Rossi GP, Golib-Dzib JF, Fischer E, Amar L, Mulatero P, Samson-Couterie B, Hahner S, Quinkler M et al. Prevalence, clinical, and molecular correlates of KCNJ5 mutations in primary aldosteronism. Hypertension $2012 \mathbf{5 9}$ 592-598. (doi:10.1161/HYPERTENSIONAHA.111.186478)

82 Barreau O, Assie G, Wilmot-Roussel H, Ragazzon B, Baudry C, Perlemoine K, Rene-Corail F, Bertagna X, Dousset B, Hamzaoui N et al. Identification of a $\mathrm{CpG}$ island methylator phenotype in adrenocortical carcinomas. Journal of Clinical Endocrinology and Metabolism 201398 E174-E184. (doi:10.1210/jc.2012-2993)

83 Xekouki P, Hatch MM, Lin L, Rodrigo de A, Azevedo M, de la Luz Sierra M, Levy I, Saloustros E, Moraitis A, Horvath A et al. KCNJ5 mutations in the National Institutes of Health cohort of patients with primary hyperaldosteronism: an infrequent genetic cause of Conn's syndrome. Endocrine-Related Cancer 201219 255-260. (doi:10.1530/ERC-12-0022)

84 Beuschlein F, Boulkroun S, Osswald A, Wieland T, Nielsen HN, Lichtenauer UD, Penton D, Schack VR, Amar L, Fischer E et al. Somatic mutations in ATP1A1 and ATP2B3 lead to aldosteroneproducing adenomas and secondary hypertension. Nature Genetics 201345 440-444. (doi:10.1038/ng.2550)

85 Akerstrom T, Crona J, Delgado Verdugo A, Starker LF, Cupisti K, Willenberg HS, Knoefel WT, Saeger W, Feller A, Ip J et al. Comprehensive re-sequencing of adrenal aldosterone producing lesions reveal three somatic mutations near the kcnj5 potassium channel selectivity filter. PLoS ONE 20127 e41926. (doi:10.1371/journal.pone.0041926)

86 Azizan EA, Murthy M, Stowasser M, Gordon R, Kowalski B, Xu S, Brown MJ \& O'Shaughnessy KM. Somatic mutations affecting the selectivity filter of KCNJ5 are frequent in 2 large unselected collections of adrenal aldosteronomas. Hypertension 201259 587-591. (doi:10.1161/HYPERTENSIONAHA.111.186239)

87 Monticone S, Hattangady NG, Nishimoto K, Mantero F, Rubin B, Cicala MV, Pezzani R, Auchus RJ, Ghayee HK, Shibata H et al. Effect of KCNJ5 mutations on gene expression in aldosteroneproducing adenomas and adrenocortical cells. Journal of Clinical Endocrinology and Metabolism 201297 E1567-E1572. (doi:10. 1210/jc.2011-3132)

88 Azizan EA, Lam BY, Newhouse SJ, Zhou J, Kuc RE, Clarke J, Happerfield L, Marker A, Hoffman GJ \& Brown MJ. Microarray, qPCR, and KCNJ5 sequencing of aldosterone-producing adenomas reveal differences in genotype and phenotype between zona glomerulosa- and zona fasciculata-like tumors. Journal of Clinical Endocrinology and Metabolism 201297 E819-E829. (doi:10. 1210/jc.2011-2965)

89 Taguchi R, Yamada M, Nakajima Y, Satoh T, Hashimoto K, Shibusawa N, Ozawa A, Okada S, Rokutanda N, Takata D et al. Expression and mutations of KCNJ5 mRNA in Japanese patients with aldosterone-producing adenomas. Journal of Clinical Endocrinology and Metabolism 201297 1311-1319. (doi:10.1210/ jc.2011-2885)

Received 18 March 2013

Accepted 8 April 2013 